\title{
MicroRNAs in Molecular Technology to Address Global Disease Bench to Bedside Research
}

\author{
Noor UL Ain Akram ${ }^{1}$, Zainab Shahzor ${ }^{1}$, Iram Mushtaq ${ }^{1}$, Ayesha Ishtiaq ${ }^{1}$, Khadam Hussain $^{1}, \operatorname{Iram~Murtaza}^{1 *}$ \\ ${ }^{1}$ Signal transduction Laboratory, Department of Biochemistry, Faculty of Biological Sciences, Quaid-i-Azam University, Islamabad, 45320, Pakistan.
}

(1st International Conference on Applied Engineering and Natural Sciences ICAENS 2021, November 1-3, 2021)

(DOI: 10.31590/ejosat.1011033)

ATIF/REFERENCE: Akram, N. U. A., Shahzor, Z., Mushtaq, I., Ishtiaq, A., Hussain, K. \& Murtaza, I. (2021). MicroRNAs in Molecular Technology to Address Global Disease Bench to Bedside Research. European Journal of Science and Technology, (28), 1492-1500.

\begin{abstract}
MicroRNAs a category of noncoding RNA dysregulations are involved in numerous pathological conditions including cancer, diabetes, heart diseases, immunological disorders, neurological diseases and many metabolic diseases. Advancement in the knowledge of microRNA applications led to the diagnosis of some early markers of diseases. Currently innovative molecular biotechnology is holding promising future in the field of application of microRNA silencers and inhibitors, replacers and over expressers for tackling life threatening diseases. RNA seq libraries of mega patients groups in the field of cancer include the expression profile of multiple microRNAs but there is need of time to develop such libraries of miRNAs in other diseases too. It will facilitate scientist in future to judge the perspective of microRNA applications in multiple clinical scenarios by simple bioinformatics analysis.
\end{abstract}

Keywords - microRNAs, diagnostic markers, applications

\section{Küresel Hastalık Tezgâhından Başucu Araştırmasına Yönelik Moleküler Teknolojideki mikroRNA'lar}

$\ddot{O} \mathbf{z}$

MikroRNA'lar, kodlamayan RNA düzensizliklerinin bir kategorisi, kanser, diyabet, kalp hastalıkları, immünolojik bozukluklar, nörolojik hastalıklar ve birçok metabolik hastalık dahil olmak üzere çok sayıda patolojik durumda yer alır. MikroRNA uygulamaları bilgisindeki ilerleme, bazı erken hastalık belirteçlerinin teşhisine yol açtı. Halihazırda yenilikçi moleküler biyoteknoloji, yaşamı tehdit eden hastalıklarla mücadele için mikroRNA susturucuları ve inhibitörleri, ikame ediciler ve aşırı ifade edicilerin uygulanması alanında gelecek vaat ediyor. Kanser alanındaki mega hasta gruplarının RNA dizi kütüphaneleri, çoklu mikroRNA'ların ekspresyon profilini içerir, ancak diğer hastalıklarda da bu tür mikroRNA kütüphanelerini geliştirmek için zamana ihtiyaç vardır. Gelecekte bilim adamlarının basit biyoinformatik analizi ile çoklu klinik senaryolarda mikroRNA uygulamalarının perspektifini yargılamasını kolaylaştıracaktır.

Anahtar Kelimeler: mikroRNA'lar, teşhis belirteçleri, uygulamalar.

\footnotetext{
* Prof. Dr. Iram Murtaza; (irambch@qau.edu.pk) orcid.org/0000-0001-8092-5211
} 


\section{Introduction}

Non-coding RNAs are the highly functional and vibrant nucleic acids involved in various physiological and pathological processes of cellular differentiation, growth and cell cycle regulation, immunity, stress response, angiogenesis, nervous system development and acts as biomarkers in identification of many diseases [1]. These small RNA molecules are referred to as micro RNAs (mi-RNAs) regulate the process of RNA interference (RNAi) which results in gene silencing or translational repression and hence regulates the expression of genes [2]. Numerous researches have been conducted that show the association of microRNAs with several pathologies [3, 4]. Cancer and cardiovascular diseases are the leading cause of mortality worldwide. Despite of the vast basic and clinical research on respective fields, it still tops in causing morbidity and mortality $[5,6]$. Cancer is characterized by uncontrolled cell division and proliferation [7]. Cardiac hypertrophy is a condition of abnormal cardiomyocyte enlargement accompanied by ventricular wall thickening [8]. Various bioinformatics tools are used for identification of novel molecular therapeutic interventions for the treatment these diseases [9, 10]. We have aimed to investigate the role of different micro RNAs in regulating the expression of different biomarkers involved in pathogenesis of diseases progression. National Centre of Biotechnology Information (NCBI) gene testing registry (GTR) was used to extract the names of the genes involved in cancer and cardiac hypertrophy. Target Scan human (7.2.2018) predicted the miRNA targets for all the genes. Some novel miRNA and gene relations have been predicted, directs us to develop new miRNA biomarkers for the diagnosis of cancer and cardiac hypertrophy.

\section{Materials and Method}

\section{A- Selection of genes from National Centre of Biotechnology Information (NCBI) gene testing registry (GTR)}

The National Centre for Biotechnology Information (NCBI) is a database which stores the information related to biomedicine and biotechnology. It gathers the information from many other databases including NCBI epigenomics and PubMed. NCBI houses the information regarding the diseases and the genes involved in the disease. We accessed NCBI webpage and searched for cancer and cardiac hypertrophy genes sequencing panel (Figure 1A).

\section{B- Insilico prediction of micro-RNA target genes through Target Scan}

The bases of miRNA target prediction vary in different softwares. miRTarBase, miRDB, miRWalk, miRGator [11], miRSystem [12], are the tools which are used for the prediction of mi-RNA targets and are most widely used softwares as they help in comparing the data from various other popular tools by detailed statistical analysis. SVMicrO [13], miRanda [14], PITA [15] and TargetScan [16] are the most widely used popular miRNA prediction tools.

Target Scan is one of the widely used softwares for predicting miRNA targets. It predicts the miRNA targets by searching the conserved sites (Figure 1B). Amongst these conserved sites, $8 \mathrm{mer}$, $7 \mathrm{mer}$ and $6 \mathrm{mer}$ sites are considered which match a specific region in the miRNA known as seed region. We filtered furthur based on conservation of miRNA among three species (human, rat and mouse) and $8 \mathrm{nt}$ target analysis (Figure 1C). It also provides with the percentile score and context ++ scores which help in predicting authenticity of the data.

The webpage of target scan softwares opens with the options of either entering the gene name or the miRNA name to search into the database for the relative targets. We used target scan software and entered the names of all the genes involved in the formation of cancer and cardiac hypertrophy as reported by NCBI. We selected the specie (human, rats and mouse) and then we proceeded by entering the names of our genes and obtained the details of miRNA targets for various sites. We also used the alternative method by entering the names of our miRNAs in the given second bar and from there on we got the detailed overview of the genes that have the same miRNA targets, and we found our respective genes from the whole given data and then found the details of the conserved sites and position of miRNAs.

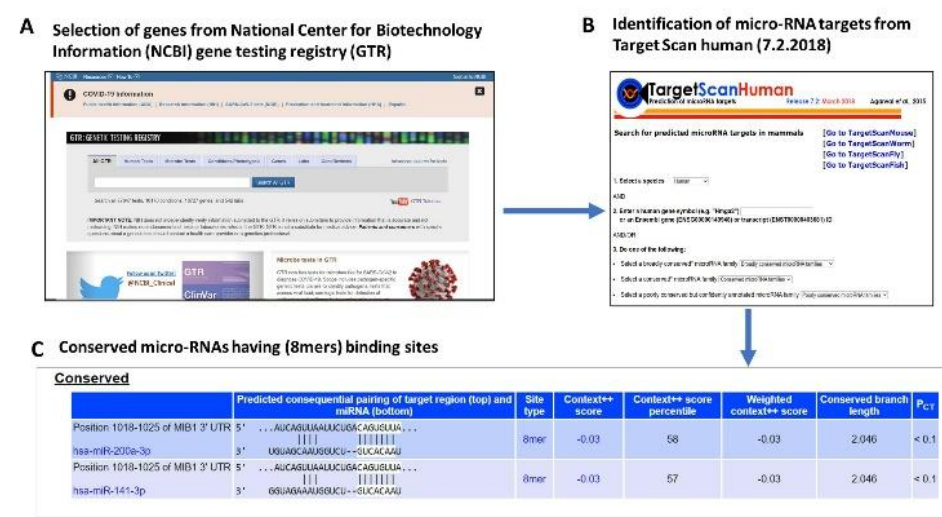

Fig. 1. Bioinformatic tool analysis A) Selection of genes from NCBI (GTR) B) Predicted miRNA through target scan C) Conserved miRNA having (8mers) binding sites.

\section{Results}

Commonly expressed miRNAs and regulated target genes involved in cancer and cardiac hypertrophy

We have examined 24 micro RNAs involved in both cancer and cardiac hypertrophy (Figure 2). For Instance, miR-30-5p is thought to be major player in regulations of genes function in cancer and cardiac hypertrophy. TSC1(Tuberous Sclerosis 1 Protein) is a tumour suppressor gene, and play role in development of vascular tissue [17]. Its expression is regulated by miR-30-5p (Position: 500-506 3' UTR, Chr:6). ACTC1 (Actin Alpha Cardiac Muscle 1), Position: 105-112 3' UTR, Chr:6 [18], ABCC9 (ATP Binding Cassette Subfamily C Member 9) Position 2962-2969 3' UTR, Chr:6 [19], and MIB1(MIB E3 Ubiquitin Protein Ligase 1) Position 1370-1377 3' UTR, Chr:6 [20] are biomarkers involved in cardiac hypertrophy and are regulated by miR-30-5p. The miR-26-5p (Position: 1261-2626 3'UTR, Chr:10), which is a target for PTEN gene is associated with breast cancer [21].

The miR-218-5p (Position: 417-423 3'UTR, Chr: 10), which is a target of the RET gene is involved mainly gastric cancers [22], bladder cancer and cardiovascular disorders [23, 24]. Many others micro RNAs and their targets are enlisted in (Figure 2). 


\section{miRNAs and regulated target genes cardiac hypertrophy}

We have examined 26 genes involved in progression of cardiac hypertrophy regulated by micro RNAs having 8-nt binding seed region. (Figure 3A).

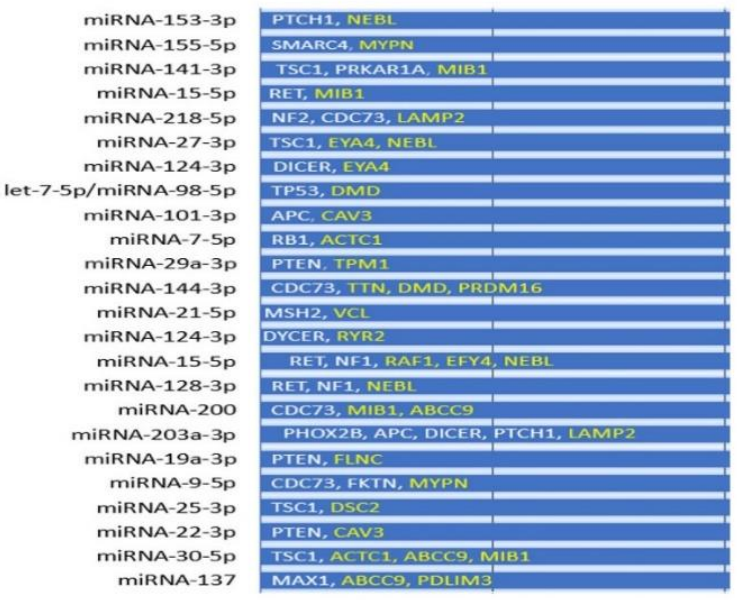

Fig. 2: List of common micro RNAs involved in cancer and cardiac hypertrophy. White color represents genes targets involved in cancer. Yellow color represents genes targets involved in cardiac hypertrophy.

M1B1 (E3 Ubiquitin-Protein Ligase MIB1) [25] expression is regulated by more than 12 micro RNAs, PRDM16 (MDS1/EVI1-Like Gene 1) [26] is regulated by 11 micro RNAs and NEBL is regulated by 10 micro RNAs. We have presented the graphical representation of all important genes and their respective 8-nt micro RNAs (Figure 3A).

We have also presented different genes targets regulated by more than one number of micro RNAs Figure 3B), Table 1. M1B1 expression is regulated by 10 micro RNAs, PRDM16 by 7 micro RNAs, and RYR2 by 7 micro RNAs.

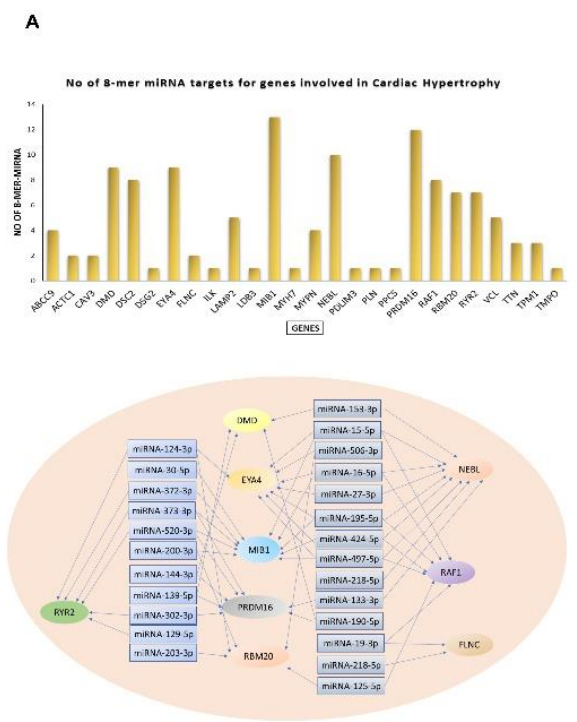

Fig. 3: miRNA targets of genes involved in cardiac hypertrophy A) Graphical representation of gene targets regulated by 8 -nt miRNAs B) Genes regulated by more than one number of miRNAs

\section{miRNAs and regulated target genes involved in cancer}

We have examined 28 genes involved in cancer regulated by more than one micro RNAs having 8-nt binding sites with their respective target genes (Figure 4A). NF1[27], CDC 37 [28] APC [29] are regulated by 7 micro RNAs and PTEN [30] is regulated by 8 micro RNAs. We have also presented different genes targets regulated by more than one number of micro RNAs (Figure 4B). Different genes targets regulated by multiple micro RNAs are shown in Table 2. The miR-155-5p (Position: 251-257 3'UTR, Chr: 1), found as a target of the CDC73 gene promotes the process of autophagy in the case of cervical cancers [31]. The miR-190-5p (Position: 90-96 3'UTR, Chr: 12), found as a target of CDC73 is not reported to play any direct role in causing endocrine neoplasia, however, it seems to affect the metabolic pathways [32]. The miR-148 (Position: 1144-1150 3'UTR, Chr: 14), found as a target of MAX1 gene, upregulation of miR-148 leads to reduced inflammation [33]. The miR34/449-5p (Position: 413-419 3'UTR, Chr: 1), which is a target of SDHC gene is involved in causing head and neck cancer [34]. The miR-802 (Position: 29-36 3'UTR, Chr: 11),_which is a target of SDHD is reported to be linked with the suppression of gastric cancer [35]. The miR-17-5p (Position:515-522 3'UTR, Chr: 2), which is a target of TMEM127 gene is linked with the hepatocellular carcinoma [36]. The miR-122-5p (Position:200206 3'UTR, Chr: 17), which is a target of TP53 gene is linked osteosarcoma [37], neuronal damage and many other cancers. The miR-223-3p (Position: 146-152 3'UTR, Chr: 3), which is a target of VHL gene is reported to be linked with thyroid carcinoma and it is a potent marker for identifying low grade thyroid carcinoma. 
Table. 1 List of miRNAs targeting different genes involved in Cardiac hypertrophy

\begin{tabular}{|c|c|c|}
\hline S. No & Putative Target Gene & miRNA \\
\hline 1 & ABCC9 & miRNA-137, miRNA-30-5p, miRNA-200-3p, miRNA-429 \\
\hline 2 & ACTC1 & miR-30-5p, miR-7-5p \\
\hline 3 & CAV3 & $\operatorname{miR}-22-3 p, \operatorname{miR}-101-3 p$ \\
\hline 4 & DMD & $\begin{array}{l}\text { miR-153-3p,miR-144-3p,miR-142-5p,miR-139-5p, miR-190-5p,let-7-5p,miR- } \\
\text { 98-5p,miR-4500,miR-4458 }\end{array}$ \\
\hline 5 & DSC2 & $\begin{array}{l}\text { miR-25-3p, miR-205-5p, miR-32-5p,miR-92-3p, miR-363-3p, miR-367-3p,miR- } \\
\text { 148-3p,miR-152-3p }\end{array}$ \\
\hline 6 & EYA4 & $\begin{array}{l}\text { miR-506-3p, miR-145- 5p, miR-124- 3p, miR-27- 3p, miR-15- 5p, miR-16- 5p, } \\
\text { miR-195- 5p, miR-424- 5p, miR-497- 5p }\end{array}$ \\
\hline 7 & FLNC & $\operatorname{miR}-19-3 p, \operatorname{miR}-218-5 p$ \\
\hline 8 & ILK & $\operatorname{miR}-542-3 p$ \\
\hline 9 & LAMP2 & miR-203-3p, miR-183-5p, miR-365-3p, miR-218-5p, miR-140-5p \\
\hline 10 & LDB3 & $\operatorname{miR}-205-5 p$ \\
\hline 11 & MIB1 & $\begin{array}{l}\operatorname{miR}-200-3 p, \operatorname{miR}-141-3 p, \text { miR-15-5p, miR-16- 5p, miR-195- 5p, miR-424- } \\
\text { 5p, miR-497- 5p, miR-30- 5p, miR-302- 5p, miR-372- 3p, miR-373- 3p, miR- } \\
\text { 520- 3p, miR-30- 5p }\end{array}$ \\
\hline 12 & MYPN & miR-9-5p, miR-24- 3p, miR-129- 5p, miR-155- 5p \\
\hline 13 & NEBL & $\begin{array}{l}\text { miR-128-3p, miR-15- 5p, miR-16- 5p, miR-195- 5p, miR-424- 5p, miR-497- } \\
\text { 5p, miR-133- 3p, miR-218- 5p, miR-27- 3p, miR-153- 3p }\end{array}$ \\
\hline 14 & PDLIM3 & miR-137 \\
\hline 15 & PLN & $\operatorname{miR}-425-5 p$ \\
\hline 16 & PRDM16 & $\begin{array}{l}\text { miR-133-3p, miR-144- 3p, miR-139-5p, miR-96- 5p, miR-1271- 5p, miR-219- } \\
\text { 5p, miR-302- 3p, miR-372- 3p, miR-373- 3p, miR-520- 3p, miR-190- 5p, }\end{array}$ \\
\hline 17 & RAF1 & $\begin{array}{l}\text { miR-15-5p, miR-16- 5p, miR-195- 5p, miR-424- 5p, miR-497- 5p, miR-19- 3p, } \\
\text { miR-125- 5p, miR-7- 5p }\end{array}$ \\
\hline 18 & RBM20 & $\begin{array}{l}\operatorname{miR}-125-5 p, \operatorname{miR}-124-3 p, \text { miR-506- 3p, miR-217, miR-26- 5p, miR-200-3p, } \\
\text { miR-203-3p }\end{array}$ \\
\hline 19 & RYR2 & $\begin{array}{l}\operatorname{miR}-124-3 p, \operatorname{miR}-302-3 p, \text { miR-372- 3p, miR-373-3p, miR-520- 3p, miR-455- } \\
3 p, \text { miR-129- 5p }\end{array}$ \\
\hline 20 & VCL & miR-21-5p, miR-590- 5p, miR-193-5p, miR-103-3p, miR-107 \\
\hline 21 & TTN & miR-144-3p, miR-451, miR-183-5p \\
\hline 22 & TPM1 & miR-29-3p, miR-183- 5p, miR-142-3p \\
\hline 23 & TMPO & miR-139-5p \\
\hline
\end{tabular}


Table. 2 List of miRNAs targeting different genes involved in Cancer

S. NO PUTATIVE TARGET GENE MIRNAS

\begin{tabular}{|c|c|c|}
\hline 1 & MAX & miRNA-137 \\
\hline 2 & SDHC & miRNA-365-3p \\
\hline 3 & MSH2 & miRNA-21-5p \\
\hline 4 & SMARCB1 & miRNA-1-3p \\
\hline 5 & SMARCA4 & miRNA-155-5p, miRNA-489-3p \\
\hline 6 & Tp53 & let-7-5p, miRNA-150-5p \\
\hline 7 & AIP & miRNA-199-5p, miRNA-204-5p \\
\hline 8 & RET & miRNA-15-5p, miRNA-128-3p \\
\hline 9 & SUFU & miRNA-129-3p, miRNA-194-5p \\
\hline 10 & PHOX2B & miRNA-203a-3p, miRNA-204-5p \\
\hline 11 & NF2 & miRNA-489-3p, miRNA-218-5p \\
\hline 12 & CDKN1B & miRNA-142-3p, miRNA-221-3p, miRNA-24-3p \\
\hline 13 & SDHD & miRNA-802, miRNA-204-5p, miRNA-23-3p \\
\hline 14 & VHL & miRNA-204-5p, miRNA-142-5p, miRNA-181-5p \\
\hline 15 & SMARCE1 & $\begin{array}{l}\text { miRNA-103-3p, miRNA-135-5p, miRNA-302-3p, } \\
\text { miRNA-19-3p }\end{array}$ \\
\hline 16 & TSC1 & $\begin{array}{l}\text { miRNA-141-3p, miRNA-25-3p, miRNA-30-5p, miRNA- } \\
27-3 p \text {, miRNA-130-3p }\end{array}$ \\
\hline 17 & TMEM127 & $\begin{array}{l}\text { miRNA-17-5p, miRNA-202-5p, miRNA-212-5p, miRNA- } \\
181-5 p \text {, miRNA-140-3p }\end{array}$ \\
\hline 18 & RB1 & $\begin{array}{l}\text { miRNA-199-3p, miRNA-26-5p, miRNA-132-3p, miRNA- } \\
\text { 7-5p, miRNA-192-5p }\end{array}$ \\
\hline 19 & MSH6 & $\begin{array}{l}\text { miRNA-103-3p, miRNA-499a-5p, miRNA-216a-5p, } \\
\text { miRNA-155-5p }\end{array}$ \\
\hline 20 & $\mathbf{A P C}$ & $\begin{array}{l}\text { miRNA-29-3p, miRNA-135-5p, miRNA-142-3p, miRNA- } \\
\text { 129-5p, miRNA-203a-3p, miRNA-26-5p, miRNA-802, } \\
\text { miRNA-101-3p }\end{array}$ \\
\hline 21 & NF1 & $\begin{array}{l}\text { miRNA-103-3p, miRNA-137, miRNA-19-3p, miRNA- } \\
\text { 128-3p, miRNA-27-3p, miRNA-15-5p, miRNA-30-5p, } \\
\text { miRNA-182-5p, miRNA-217 }\end{array}$ \\
\hline 22 & DICER & $\begin{array}{l}\text { miRNA-182-5p, miRNA-124-3p, miRNA-29-3p, miRNA- } \\
\text { 190-5p, miRNA-103-3p, miRNA-221-3p, miRNA-203-3p }\end{array}$ \\
\hline 23 & PRKAR1A & $\begin{array}{l}\text { miRNA-155-5p, miRNA-141-3p, miRNA-183-5p, } \\
\text { miRNA-96-5p, miRNA-499a-5p, miRNA-455-3p, } \\
\text { miRNA-192-5p }\end{array}$ \\
\hline 24 & PTCH1 & $\begin{array}{l}\text { miRNA-140-3p, miRNA-153-3p, miRNA-101-3p, } \\
\text { miRNA-203a-3p, miRNA-141-3p }\end{array}$ \\
\hline 25 & PTEN & $\begin{array}{l}\text { miRNA-388-3p, miRNA-29-3p, miRNA-22-3p, miRNA- } \\
\text { 103-3p, miRNA-19-3p, miRNA-26-5p, miRNA-23-3p, } \\
\text { miRNA-148-3p, miRNA-499a-5p }\end{array}$ \\
\hline 26 & CDC73 & $\begin{array}{l}\text { miRNA-182-5p, miRNA-218-5p, miRNA-200, miRNA- } \\
\text { 144-3p, miRNA-181-5p, miRNA-9-5p, miRNA-101-3p } \\
\text { miRNA-130-3p }\end{array}$ \\
\hline
\end{tabular}




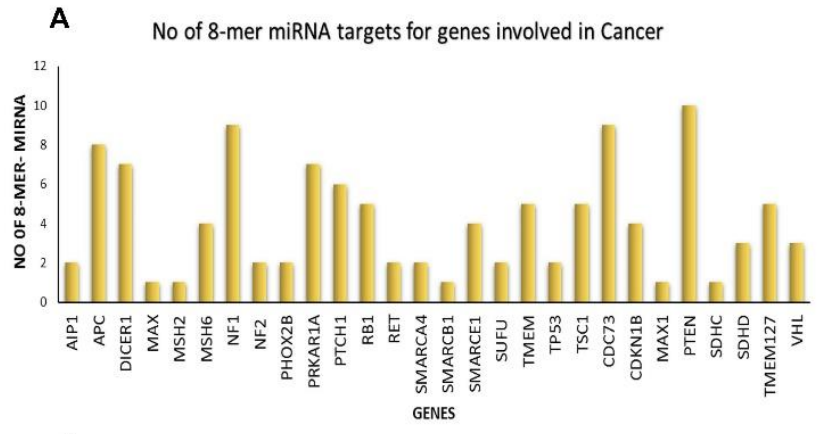

B

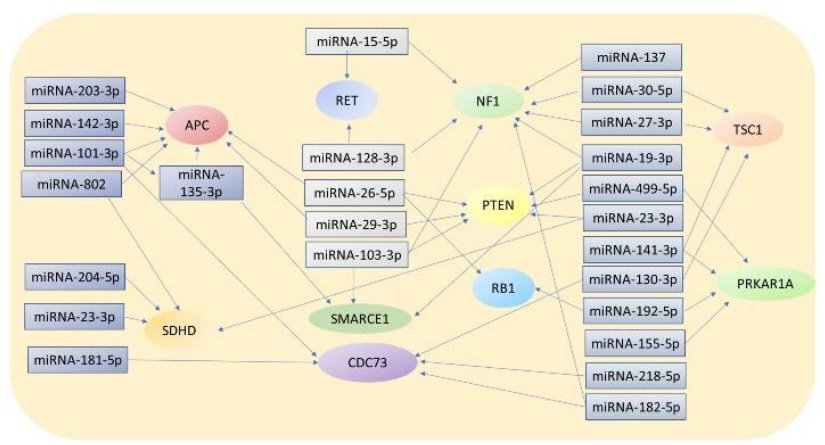

Fig. 4: miRNA targets for genes involved cancer A) Graphical representation of gene targets regulated by 8 -nt miRNAs B) Genes regulated by more than one micro RNAs

\section{Discussion}

Exploration of miRNAs to identify their functioning and roles in diseases is being carried out extensively. MicroRNAs have proved to be essential gene expression regulators thereby manifesting in several diseases. Furthermore, they carry a potential to serve as emerging biomarkers for numerous diseases. In this study, we have described a computational strategy using bionformatic tools for the identification of candidate master miRNA regulators of genes involved in both cancer and cardiac hypertrophy through high-quality training datasets. We have performed target prediction analyses with the most stringent conservation criteria among (human, rat and mouse) and filtered 8-nt miRNAs regulates many target genes involved in cellular processes.

Our results predicted many master regulators which are common in both cancer and cardiac hypertrophy. Furthure more, we have expolered 8-nt binding teargets genes involved in cancer as well as in cardiac hypertrophy. TargetScan analyses showed NF1, RET and MIB1 genes as a target of miR-15. This microRNA has been reported to induce tumor inhibitory effects. Study conducted by Lu et al has shown that miR-15 lessens the proliferation and migration of thyroid cancer cells. It displays these effects by targeting BCL2 gene, which is highly expressed in cancer cells [38]. Researchers are working on miR-15 based therapeutic for chronic lymphocytic leukemia by targeted inhibition of BCL2 [39]. These studies make miR-15 an attractive microRNA to be used against brain cancer and cardiac hypertrophy by selectively targeting gene targets. The miR-1555p (Position: 164-171 3'UTR, Chr: 17), is also related to PRKAR1A gene. miR-155-5p promotes the autophagy in cervical cancers [40].
Through literature survey, we identified several genes reported in cardiac hypertrophy (Table 1) and cancers (Table 2). Various studies on MSH6, a DNA mismatch repair (MMR) protein coding gene showed its involvement in brain cancers. MSH6 together with MSH2 forms a protein complex, which is responsible for the DNA repair. A study conducted in glioblastoma reported mutation in 4th exon of MSH6, which led to alterations in its gene expression [41]. In a similar study conducted on glioma cell lines by Xie et al, mutation in MSH6 led to wide-ranging genome hyper-mutations and resistance to treatment [42] From TargetScan, we identified that miR-499-5p binds with MSH6 in the seed region as an 8mer target. This miRNA has been previously reported in study conducted by Yang et al, which showed its correlation with occurrence of gastric cancer [43]. Another study conducted on lung carcinoma reinforced the positive correlation of miR-499-5p with cancer. In this study, overexpression miR-499 was linked to tumor proliferation and migration. In vitro inhibition using anti-mir499 oligonucleotides reduced tumor growth [44]. Role of miR499 against brain cancers has yet to be recognized but implying its role in other cancers, it can be thought of as a potential therapeutic target. TMEM gene family is involved in several cell functionalities like apoptosis and signaling. Various studies on this gene show the role of TMEM family as tumor enhancers and are found to be upregulated in glioblastoma. In a study conducted by Xu et al, silencing of TMEM-168 using siRNA led to inhibition of tumor proliferation [45]. In a similar study, TMEM-48 knockdown led to reduction in tumor cell invasion and migration. Qiu et al showed that TMEM97 silencing using RNA interference induced anti-tumor effects by suppressing the cell cycle transition regulators CDK2 and cyclinD1 [46]. MiR202 as predicted by TargetScan is an 8mer target of TMEM. Numerous Investigations performed on miR-202 revealed its anti-tumor properties. Study conducted on breast cancer cell lines elucidated the anti-proliferative activity of miR-202 against tumor cells. Harati showed that silencing of miR-202 leads to increase in brain invasive property of malignant breast cancer [47]. MiRNA induced TMEM silencing could be a potential therapeutic intervention for brain neoplasm. From NCBI database, SMARCE1 was identified to have a role in causation of brain neoplasm. This gene has previously been reported to be linked with cancer in several studies. In a study conducted by Liu et al, increased expression of SMARCE1 was observed the in gastric cancers where it activates the MAPK/ERK signaling pathway, leading to increased tumor proliferation [48]. In a similar study by Sokol et al., inhibition of SMARCE1 led to decreased tumor proliferation and invasion in breast cancer cell lines, thus exhibiting its oncogenic potential [49]. MiR-302 has been predicted by TargetScan as a possible 8mer target for SMARCE1. Several researches on miR-302 have revealed its anti-cancer properties. Two different studies, conducted in ovarian cancer cells and hepatocellular carcinoma cells, showed reduced expression of miR-302 in the said tumor cells. Administration of miR-302 led to a decrease in colony forming ability and proliferation of cancer cells $[50,51]$. In addition to this, investigations to discover the role of miR-302 have been performed in glioblastomas. These cancers normally express low level of miR-302. Scientists engineered the glioma cells to express normal levels of miR-302. A decrease in proliferation was observed in neighboring non-engineered glioma cells which occurred because of paracrine mode of action of the said miRNA [52]. Regulating gene expression levels of SMARCE1 by miR302 mediated gene silencing could prove to be a promising 
therapeutic intervention. Numerous researches carried out on miRNA-103 have revealed its tumor suppressive potential. In a study conducted on glioma cells, low expression levels of miR103 were detected. Administration of miR-103 in these cells led to decrease in tumor growth. MiR-103 targets brain derived neurotrophic factor (BDNF) thus inhibiting neuronal growth and maturation [53]. In a similar study conducted by Chen et al, miR-103 was shown to inhibit tumor proliferation by targeting and silencing gene expression of SALL4, a highly expressed gene in tumor cells [54]. Since a single miRNA can bind to multiple targets, miR-103 is predicted to control gene expression and silencing of several genes that include NF1, PTEN, SMARCE1, DICER 1 and MSH6. NF1 gene encodes for a protein called neurofibromin that controls cell growth. Loss of function was observed in $11 \%$ of glioblastoma cases. A genetic disorder called neurofibromatosis is caused due to inheritance of mutated NF1 (loss of functional mutation) which makes the individual five time more susceptible to brain malignancies [55].

RYR2 (Cardiac Muscle Ryanodine Receptor) gene encodes a ryanodine receptor, found in cardiac muscle sarcoplasmic reticulum, one of the components of a calcium channel, [56]. Defects in $\mathrm{Ca}^{2+}$ release from channels/ryanodine receptors (RyR2) accelerates pathological cardiac hypertophy. This gene is regulated by miR-133 [57] and miR-1 and its expression is found to be upregulated in cardiac hypertrophy [58].

Further in vivo analysis using techniques like RT-qPCR, NGS, luciferase reporter assay and western blotting is required to experimentally validate the potential therapeutic miRNAs targets predicted in this study. MiRNA based therapeutics are generally classified into two types; miRNA mimics and antagomiRs. The miRNA mimics restore normal concentration of a particular miRNA whose concentrations reduced as a result of pathology. On the contrary, antagomiRs cause silencing of overexpressed miRNAs involved in diseases. Modulating gene expression using microRNA mimics or antagonist depends on the role of target gene. Working on miRNA based therapeutic is being done by numerous biotechnological companies. Yet, the search of miRNAs as a prospective therapeutics for cancer and cardiac hypertrophy therapy is at the very beginning.

\section{Conclusion}

MicroRNAs can be employed as a treatment against many pathologies including cancer and cardiac hypertrophy. In this study, we limited ourselves to In silico bioinformatic analysis using NCBI databases as well as target Scan. Our findings suggested some possible therapeutic targets that may be employed in treatment of diseeases. Some of the targets have not been reported previously and these newly predicted targets can help us in future to design therapeutics and establish novel biomarkers for the better diagnosis and prognosis of pathologies. To confirm our findings, in vivo and in vitro experimentations are essential.

\section{Acknowledgment}

We acknowledge Quaid-i-Azam University's URF (University Research Fund), Higher Education Commission Pakistan (HEC) and Pakistan Science Foundation (PSF) to support the current study.

\section{References}

[1]. Mushtaq I, Ishtiaq A, Ali T, Jan MI, Murtaza I. An Overview of Non-coding RNAs and Cardiovascular System. J Non-coding RNAs in Cardiovascular Diseases 2020:3-45.

[2]. Ali T, Mushtaq I, Maryam S, Farhan A, Saba K, Jan MI, et al. Interplay of $\mathrm{N}$ acetyl cysteine and melatonin in regulating oxidative stress-induced cardiac hypertrophic factors and microRNAs. J Archives of biochemistry biophysics. 2019;661:56-65.

[3]. Çakmak HA, Demir M. MicroRNA and cardiovascular diseases. J Balkan medical journal. 2020;37(2):60.

[4]. Di Z, Di M, Fu W, Tang Q, Liu Y, Lei P, et al. Integrated analysis identifies a nine-microRNA signature biomarker for diagnosis and prognosis in colorectal cancer. J Frontiers in genetics2020;11:192.

[5]. Sung H, Ferlay J, Siegel RL, Laversanne M, Soerjomataram I, Jemal A, et al. Global cancer statistics 2020: GLOBOCAN estimates of incidence and mortality worldwide for 36 cancers in 185 countries. J CA: a cancer journal for clinicians 2021;71(3):209-49.

[6]. Roth GA, Mensah GA, Johnson CO, Addolorato G, Ammirati E, Baddour LM, et al. Global burden of cardiovascular diseases and risk factors, 1990-2019: update from the GBD 2019 study. J Journal of the American College of Cardiology 2020;76(25):2982-3021.

[7]. Jose J, Kumar R, Harilal S, Mathew GE, Prabhu A, Uddin MS, et al. Magnetic nanoparticles for hyperthermia in cancer treatment: an emerging tool. J Environmental Science Pollution Research. 2020;27(16):19214-25.

[8]. Oldfield CJ, Duhamel TA, Dhalla NS. Mechanisms for the transition from physiological to pathological cardiac hypertrophy. J Canadian journal of physiology pharmacology 2020;98(2):74-84.

[9]. Zheng H, Zhang G, Zhang L, Wang Q, Li H, Han Y, et al. Comprehensive review of web servers and bioinformatics tools for cancer prognosis analysis. J Frontiers in oncology 2020;10:68

[10]. Das S, Shah R, Dimmeler S, Freedman JE, Holley C, Lee J-M, et al. Noncoding RNAs in cardiovascular disease: current knowledge, tools and technologies for investigation, and future directions: a scientific statement from the american heart association. J Circulation: Genomic Precision Medicine 2020;13(4):e000062.

[11]. Nam S, Kim B, Shin S, Lee S. miRGator: an integrated system for functional annotation of microRNAs. Nucleic acids research. 2007;36(suppl_1):D159-D64.

[12]. Lu T-P, Lee C-Y, Tsai M-H, Chiu Y-C, Hsiao CK, Lai L-C, et al. miRSystem: an integrated system for characterizing enriched functions and pathways of microRNA targets. 2012.

[13]. Liu H, Yue D, Chen Y, Gao S-J, Huang Y. Improving performance of mammalian microRNA target prediction. BMC bioinformatics. 2010;11(1):1-15.

[14]. Betel D, Koppal A, Agius P, Sander C, Leslie C. Comprehensive modeling of microRNA targets predicts functional non-conserved and non-canonical sites. Genome biology. 2010;11(8):1-14.

[15]. Kertesz M, Iovino N, Unnerstall U, Gaul U, Segal E. The role of site accessibility in microRNA target recognition. Nature genetics. 2007;39(10):1278-84. 
[16]. Agarwal V, Bell GW, Nam J-W, Bartel DP. Predicting effective microRNA target sites in mammalian mRNAs. elife. 2015;4:e05005.

[17]. Malhowski AJ, Hira H, Bashiruddin S, Warburton R, Goto J, Robert B, et al. Smooth muscle protein-22-mediated deletion of Tsc1 results in cardiac hypertrophy that is mTORC1-mediated and reversed by rapamycin. J Human molecular genetics2011;20(7):1290-305.

[18]. Cheung AS, de Rooy C, Levinger I, Rana K, Clarke MV, How JM, et al. Actin alpha cardiac muscle 1 gene expression is upregulated in the skeletal muscle of men undergoing androgen deprivation therapy for prostate cancer. J The Journal of steroid biochemistry molecular biology2017;174:56-64.

[19]. Zhang X, Kang X, Jin L, Bai J, Zhang H, Liu W, et al. ABCC9, NKAPL, and TMEM132C are potential diagnostic and prognostic markers in triple-negative breast cancer. $\mathbf{J}$ Cell Biology International

2020;44(10):2002-10.

[20]. Zhang B, Cheng X, Zhan S, Jin X, Liu T. MIB1 upregulates IQGAP1 and promotes pancreatic cancer progression by inducing ST7 degradation. J Molecular Oncology 2021.

[21]. Zhang Y, Jin W, Ma D, Cao J, Fu T, Zhang Z, et al. Long non-coding RNA CYTOR regulates proliferation and metastasis of colon cancer cells through regulating miRNA105/PTEN axis. International journal of clinical and experimental pathology. 2021;14(4):434.

[22]. Zhang T, Beeharry MK, Wang Z, Zhu Z, Li J, Li C. YY1-modulated long non-coding RNA SNHG12 promotes gastric cancer metastasis by activating the miR-218$5 \mathrm{p} / \mathrm{YWHAZ}$ axis. International journal of biological sciences. 2021;17(7):1629.

[23]. Li Y, Shi B, Dong F, Zhu X, Liu B, Liu Y. LncRNA KCNQ1OT1 facilitates the progression of bladder cancer by targeting MiR-218-5p/HS3ST3B1. Cancer Gene Therapy. 2021;28(3):212-20.

[24]. Szabadosova V, Boronova I, Ferenc P, Tothova I, Bernasovska J, Zigova M, et al. Analysis of selected genes associated with cardiomyopathy by next-generation sequencing. J Journal of clinical laboratory analysis 2018;32(2):e22254.

[25]. Kawamoto A, Kato T, Shioi T, Okuda J, Kawashima T, Tamaki Y, et al. Measurement of technetium-99m sestamibi signals in rats administered a mitochondrial uncoupler and in a rat model of heart failure. $\mathrm{J}$ PloS one. 2015;10(1):e0117091.

[26]. Mochizuki N, Shimizu S, Nagasawa T, Tanaka H, Taniwaki M, Yokota J, et al. A novel gene, MEL1, mapped to $1 \mathrm{p} 36.3$ is highly homologous to the MDS1/EVI1 gene and is transcriptionally activated in $\mathrm{t}(1 ; 3)(\mathrm{p} 36 ; \mathrm{q} 21)-$ positive leukemia cells. J Blood, The Journal of the American Society of Hematology 2000;96(9):3209-14.

[27]. Kiuru M, Busam KJ. The NF1 gene in tumor syndromes and melanoma. J Laboratory investigation. 2017;97(2):14657.

[28]. Eguchi T, Prince TL, Tran MT, Sogawa C, Lang BJ, Calderwood SKJC. MZF1 and SCAND1 Reciprocally Regulate CDC37 Gene Expression in Prostate Cancer. J Cancers 2019;11(6):792.

[29]. Zhang L, Shay JW. Multiple roles of APC and its therapeutic implications in colorectal cancer. J JNCI: Journal of the National Cancer Institute 2017;109(8).
[30]. Jamaspishvili T, Berman DM, Ross AE, Scher HI, De Marzo AM, Squire JA, et al. Clinical implications of PTEN loss in prostate cancer. $\mathrm{J}$ Nature Reviews Urology. 2018;15(4):222-34.

[31]. Wu S, Lu D, Zheng X, Xu J, Li Z, Deng L, et al. Dysregulation of autophagy-associated microRNAs in condyloma acuminatum. Infection, Genetics and Evolution. 2021:104878.

[32]. Kostyniuk DJ, Mennigen JA. Meta-analysis of differentially-regulated hepatic microRNAs identifies candidate post-transcriptional regulation networks of intermediary metabolism in rainbow trout. Comparative Biochemistry and Physiology Part D: Genomics and Proteomics. 2020;36:100750.

[33]. Yin M, Lu J, Guo Z, Zhang Y, Liu J, Wu T, et al. Reduced SULT2B1b expression alleviates ox-LDL-induced inflammation by upregulating miR-148-3P via inhibiting the IKK $\beta / \mathrm{NF}-\kappa \mathrm{B}$ pathway in macrophages. Aging (Albany NY). 2021;13(3):3428.

[34]. Wu X, Cheng Y-SL, Matthen M, Yoon A, Schwartz GK, Bala S, et al. Down-regulation of the tumor suppressor miR-34a contributes to head and neck cancer by upregulating the MET oncogene and modulating tumor immune evasion. Journal of Experimental \& Clinical Cancer Research. 2021;40(1):1-16.

[35]. Wen H-L, Xu Z-M, Lin S-Y, Wen D, Xie JP. miR-597$3 p$ inhibits invasion and migration of thyroid carcinoma SW579 cells by targeting RAB23. Endokrynologia Polska. 2021;72(1):22-8.

[36]. Duan J, Qian Y, Fu X, Chen M, Liu K, Liu H, et al. TMEM106C contributes to the malignant characteristics and poor prognosis of hepatocellular carcinoma. Aging (Albany NY). 2021;13(4):5585.

[37]. Cao J-Y, Wang B, Tang T-T, Wen Y, Li Z-L, Feng S-T, et al. Exosomal miR-125b-5p deriving from mesenchymal stem cells promotes tubular repair by suppression of p53 in ischemic acute kidney injury. Theranostics. 2021;11(11):5248.

[38]. Lu Z, Wu Z, Hu J, Wei W, Ma B, Wen D. MicroRNA15 regulates the proliferation, migration and invasion of thyroid cancer cells by targeting Bcl-2. J Journal of BU ON: official journal of the Balkan Union of Oncology 2019;24(5):2114-9.

[39]. Pekarsky Y, Balatti V, Croce CM. BCL2 and miR15/16: from gene discovery to treatment. J Cell Death Differentiation 2018;25(1):21-6.

[40]. Wang Z, Yan K, Ge G, Zhang D, Bai J, Guo X, et al. Exosomes derived from miR-155-5p-overexpressing synovial mesenchymal stem cells prevent osteoarthritis via enhancing proliferation and migration, attenuating apoptosis, and modulating extracellular matrix secretion in chondrocytes. Cell Biology and Toxicology. 2021;37(1):8596.

[41]. Deris Zayeri Z, Tahmasebi Birgani M, Mohammadi Asl J, Kashipazha D, Hajjari M. A novel infram deletion in MSH6 gene in glioma: Conversation on MSH6 mutations in brain tumors. J Journal of cellular physiology. 2019;234(7):11092-102.

[42]. Xie C, Sheng H, Zhang N, Li S, Wei X, Zheng X. Association of MSH6 mutation with glioma susceptibility, drug resistance and progression. J Molecular clinical oncology 2016;5(2):236-40. 
[43]. Yang YL, Liu P, Li D, Yang Q, Li B, Jiang XJ. Stat-3 signaling promotes cell proliferation and metastasis of gastric cancer through PDCD4 downregulation. J The Kaohsiung journal of medical sciences 2020;36(4):244-9.

[44]. He S, Li Z, Yu Y, Zeng Q, Cheng Y, Ji W, et al. Exosomal miR-499a-5p promotes cell proliferation, migration and EMT via mTOR signaling pathway in lung adenocarcinoma. J Experimental cell research. 2019;379(2):203-13.

[45]. Xu J, Su Z, Ding Q, Shen L, Nie X, Pan X, et al. Inhibition of proliferation by knockdown of Transmembrane (TMEM) 168 in Glioblastoma cells via suppression of Wnt/ $\beta$-catenin pathway. J Oncology research 2019;27(7):819.

[46]. Qiu G, Sun W, Zou Y, Cai Z, Wang P, Lin X, et al. RNA interference against TMEM97 inhibits cell proliferation, migration, and invasion in glioma cells. J Tumor Biology 2015;36(10):8231-8.

[47]. Harati R, Hafezi S, Mabondzo A, Tlili A. Silencing miR-202-3p increases MMP-1 and promotes a brain invasive phenotype in metastatic breast cancer cells. J PloS one. 2020;15(10):e0239292.

[48]. Liu H, Zhao Y-R, Chen B, Ge Z, Huang J-S. High expression of SMARCE1 predicts poor prognosis and promotes cell growth and metastasis in gastric cancer. J Cancer management research. 2019;11:3493.

[49]. Sokol ES, Feng Y-X, Jin DX, Tizabi MD, Miller DH, Cohen MA, et al. SMARCE1 is required for the invasive progression of in situ cancers. J Proceedings of the National Academy of Sciences 2017;114(16):4153-8.

[50]. Ge T, Yin M, Yang M, Liu T, Lou G. MicroRNA-302b suppresses human epithelial ovarian cancer cell growth by targeting RUNX1. J Cellular physiology biochemistry. 2014;34(6):2209-20.

[51]. Wang L, Yao J, Shi X, Hu L, Li Z, Song T, et al. MicroRNA-302b suppresses cell proliferation by targeting EGFR in human hepatocellular carcinoma SMMC-7721 cells. J BMC cancer. 2013;13(1):1-9.

[52]. Fareh M, Almairac F, Turchi L, Burel-Vandenbos F, Paquis P, Fontaine D, et al. Cell-based therapy using miR302-367 expressing cells represses glioblastoma growth. J Cell death 2017;8(3):e2713-e.

[53]. Wang L, Liu Y, Song J. MicroRNA-103 suppresses glioma cell proliferation and invasion by targeting the brainderived neurotrophic factor. J Molecular medicine reports. 2018;17(3):4083-9.

[54]. Chen L-P, Zhang N-N, Ren X-Q, He J, Li Y. miR03/miR-195/miR-15b regulate SALL4 and inhibit proliferation and migration in glioma. $\mathbf{J}$ Molecules 2018;23(11):2938.

[55]. Cockey E, Ullrich N. Neurofibromatosis typ 1associated brain tumors. J Journal of Rare Diseases Research Treatment. 2016;1(2).

[56]. van Oort RJ, Respress JL, Li N, Reynolds C, De Almeida AC, Skapura DG, et al. Accelerated development of pressure overload-induced cardiac hypertrophy and dysfunction in an RyR2-R176Q knockin mouse model. J Hypertension 2010;55(4):932-8.

[57]. Belevych AE, Sansom SE, Terentyeva R, Ho H-T, Nishijima Y, Martin MM, et al. MicroRNA-1 and-133 increase arrhythmogenesis in heart failure by dissociating phosphatase activity from RyR2 complex. J PloS one. 2011;6(12):e28324.
[58]. Terentyev D, Belevych AE, Terentyeva R, Martin MM, Malana GE, Kuhn DE, et al. miR-1 overexpression enhances $\mathrm{Ca} 2+$ release and promotes cardiac arrhythmogenesis by targeting PP2A regulatory subunit B56 $\alpha$ and causing CaMKII-dependent hyperphosphorylation of RyR2. J Circulation research 2009;104(4):514-21. 